\title{
Aerobic fitness and body fatness describe minimal variability in the thermoregulatory responses to exercise after accounting for heat production and body size
}

\author{
Matthew Cramer ${ }^{1}$, Ollie Jay ${ }^{1,2^{*}}$ \\ From 15th International Conference on Environmental Ergonomics (ICEE XV) \\ Portsmouth, UK. 28 June - 3 July 2015
}

\section{Introduction}

Aerobic fitness $\left(\mathrm{VO}_{2 \max }\right)$ and body fatness have been regularly suggested as important determinants of core temperature and sweating responses to exercise $[3,5]$, but recent studies suggest that biophysical factors related to heat production $\left(\mathrm{H}_{\text {prod }}\right)$, total body mass (TBM), and body surface area (BSA), predominantly influence rectal temperature changes $\left(\Delta \mathrm{T}_{\mathrm{re}}\right)$ and sweating $[1,2,4]$. The present study tested the hypotheses that (i) individual variation in $\Delta \mathrm{T}_{\mathrm{re}}$, whole-body sweat loss (WBSL), and steady-state local sweat rate $\left(\mathrm{LSR}_{\mathrm{ss}}\right)$ is determined primarily by $\mathrm{H}_{\text {prod }}\left(\mathrm{W} \cdot \mathrm{kg}^{-1} \mathrm{TBM}\right)$, evaporation required for heat balance $\left(E_{\text {req }}, W\right)$, and $E_{\text {req }}\left(W . m^{-}\right.$ ${ }^{2}$ ), respectively, and (ii) factors related to $\mathrm{VO}_{2 \max }$ and body fat percentage (BF\%) contribute minimally to the residual variance in these responses.

\section{Methods}

Twenty-eight male subjects [TBM: 78.2(11.3) kg, BSA: 1.96(0.15) $\left.\left.\mathrm{m}^{2}, \mathrm{VO}_{2 \max }: 3.86(0.68) \mathrm{L} \cdot \mathrm{min}^{-1}\right)\right]$ performed exercise at external workloads corresponding to a wide range of $\% \mathrm{VO}_{2 \max }(32.2-80.0 \%), \mathrm{H}_{\text {prod }}\left(5.2-12.1 \mathrm{~W} \cdot \mathrm{kg}^{-1}\right.$ $\mathrm{TBM})$, and $\mathrm{E}_{\mathrm{req}}(256-672 \mathrm{~W})$ in $24.8(0.7){ }^{\circ} \mathrm{C}$, 33.4(12.2) $\% \mathrm{RH}$, and 1.2(0.1) m. $\mathrm{s}^{-1}$ air velocity. $\mathrm{T}_{\mathrm{re}}$ and forearm LSR were measured continuously; WBSL was estimated from changes in body mass. Forward stepwise multiple regression analysis was subsequently performed and partial contributions of each independent variable were determined using standardized regression coefficients.

* Correspondence: ollie.jay@sydney.edu.au

${ }^{1}$ School of Human Kinetics, University of Ottawa, Canada

Full list of author information is available at the end of the article

\section{Results}

$\mathrm{H}_{\text {prod }}\left(\mathrm{W} . \mathrm{kg}^{-1} \mathrm{TBM}\right.$ ) alone described $\sim 50 \%$ of the variance in $\Delta \mathrm{T}_{\mathrm{re}}$ (adjusted $\mathrm{R}^{2}=0.496, \mathrm{P}<0.001$ ), while BSA-to-mass ratio and BF\% added $4.3 \%$ and $2.3 \%$, respectively, to the explained variance. For WBSL, $\mathrm{E}_{\text {req }}$ (W) alone explained $\sim 71 \%$ of the variance (adjusted $\left.\mathrm{R}^{2}=0.713, \mathrm{P}<0.001\right)$, and the inclusion of $\mathrm{BF} \%$ explained an additional $2 \%$ of the variance in WBSL. Similarly, $E_{\text {req }}\left(\mathrm{W} \cdot \mathrm{m}^{-2}\right)$ correlated significantly with $\mathrm{LSR}_{\mathrm{ss}}$ (adjusted $\mathrm{R}^{2}=0.603, \mathrm{P}<0.001$ ), while $\% \mathrm{VO}_{2 \max }$ contributed an additional $\sim 4 \%$ to the total variance.

\section{Discussion}

Previous findings that identified $\mathrm{VO}_{2 \max }$ and body fatness as important modulators of core temperature and sweating may be confounded by collinearity between independent variables, since fitter individuals tend to be lighter and leaner and thus generate more heat (in W. $\mathrm{kg}^{-1} \mathrm{TBM}$ ) and have a higher $\mathrm{E}_{\text {req }}$ (in W and W. $\mathrm{m}^{-2}$ ) at a fixed \% $\mathrm{VO}_{2 \text { max }}$, resulting in expectedly higher $\mathrm{T}_{\mathrm{re}}$ and sweating rates. The relatively minor independent contribution of $\mathrm{BF} \%$ and $\% \mathrm{VO}_{2 \max }$ to these responses warrants consideration.

\section{Conclusion}

Biophysical factors related to heat production and body size explained $\sim 54-71 \%$ of the total variability in the core temperature and thermoregulatory sweating responses to exercise in a compensable environment, with only a minor contribution $(<4 \%)$ to the explained variance in $\Delta \mathrm{T}_{\mathrm{re}}$ and WBSL by $\mathrm{BF} \%$, and $\mathrm{LSR}_{\mathrm{ss}}$ by $\%$ $\mathrm{VO}_{2 \max }$. 


\section{Authors' details}

${ }^{1}$ School of Human Kinetics, University of Ottawa, Canada. ${ }^{2}$ Thermal

Ergonomics Laboratory, Faculty of Health Sciences, University of Sydney,

Australia.

Published: 14 September 2015

\section{References}

1. Cramer MN, Jay O: J Appl Physiol 2014, 116:1123-1132.

2. Gagnon D, Jay O, Kenny GP: J Physiol 2013, 591:2925-35.

3. Greenhaff PL, Clough PJ: Eur J Appl Physiol Occup Physiol 1989, 58:348-52.

4. Jay O, Bain AR, Deren TM, Sacheli M, Cramer MN: Am J Physiol Regul Integr Comp Physiol 2011, 301:R832-41.

5. Mora-Rodriguez R: Exerc Sport Sci Rev 2012, 40:79-87.

doi:10.1186/2046-7648-4-S1-A11

Cite this article as: Cramer and Jay: Aerobic fitness and body fatness describe minimal variability in the thermoregulatory responses to exercise after accounting for heat production and body size. Extreme Physiology \& Medicine 2015 4(Suppl 1):A11.

\section{Submit your next manuscript to BioMed Central} and take full advantage of:

- Convenient online submission

- Thorough peer review

- No space constraints or color figure charges

- Immediate publication on acceptance

- Inclusion in PubMed, CAS, Scopus and Google Scholar

- Research which is freely available for redistribution

Submit your manuscript at www.biomedcentral.com/submit
() Biomed Central 